\title{
第60回 日本視能矯正学会
}

\section{一般講演}

\section{単焦点眼内レンズ挿入眼における術後眼鏡不要群の特性}

馬服つかさ・仲村 永江・宮田 律子・佐々木由佳・ 御田村 睦・河本 絢香・岡垣 あき・山田 晴彦

\section{Characteristics of the patients without spectacles wear in monofocal intraocular lens implanted eyes Characteristics of the Patients with Monofocal Intraocular Lens Implantation Who Did Not Require Postoperative Spectacle Wear}

\author{
Tsukasa Mabara, Hisae Nakamura, Ritsuko Miyata, Yuka Sasaki, \\ Mutsumi Mitamura, Ayaka Kawamoto, Aki Okagaki, Haruhiko Yamada
}

Department of Ophthalmology, Kansai Medical University

要 約

【目的】単焦点眼内レンズを挿入した患者（以下、IOL眼）でも術後眼鏡装用なしで満足の得られ る症例があることから、IOL眼における眼鏡不要者の特性を調査した。

【対象及び方法】2017年 3 月から 2018年7月までに関西医科大学附属病院で両眼の白内障手術を施 行した症例のうち、白内障以外の眼疾患を有しない 129 名（平均年齢 $74.0 \pm 8.2$ 歳）に対し眼鏡使用 について調查した。眼鏡使用状況から不要群 (34名、26\%)、遠用眼鏡群 $(29$ 名、22\%)、近用眼鏡 群（66名、 $51 \%$ ）とし、屈折、視力、眼軸長、瞳孔径、眼鏡使用歴について比較検討を行った。な お術後遠近両用眼鏡使用者は除外した。

【結果】術後等価球面值（以下、SE）の中央值は不要群 $-0.56 \mathrm{D}$ 、遠用眼鏡群 $-3.13 \mathrm{D}$ 、近用眼鏡群 $-0.13 \mathrm{D}$ であった。術後両眼開放裸眼視力は $5 \mathrm{~m}$ で近用眼鏡群が有意に良好で、 $32 \mathrm{~cm}$ では遠用眼鏡群 が有意に良好であった。眼軸長は遠用眼鏡群が他群と比較して有意に長眼軸であった。術前の眼鏡 使用状況については不要群で術前眼鏡不使用者が有意に多かった。 $(\mathrm{p}<0.01)$

【結論】IOL眼で眼鏡不要であった症例は、両眼ともに術後 SE-0.50D -1.00D 以内の軽度近視で術 前に眼鏡不使用であった患者が多かった。

別冊請求先（广 573-1191）大阪府枚方市新町 2-3-1

Tel. 072 (804) $0101 \quad$ Fax. $072(804) 2889$

E-mail : t_mabara_hirakata@yahoo.co.jp

Key words：単焦点眼内レンズ、術後眼鏡装用、軽度近視 monofocal intraocular lens, postoperative spectacle wear, mild myopia 


\section{Abstract}

【Purpose】 We evaluated the characteristics of the patients who had received monofocal intraocular lens (IOL) implantation and had been satisfied with their postoperative vision without spectacle wear.

【Subjects and Methods】 We retrospectively reviewed the medical records of 129 patients (average age, $74.0 \pm 8.2$ years) with no other ocular diseases except cataract, who had undergone cataract surgery with monofocal IOL implantation at Kansai Medical University between March 2017 and March 2018. The patients' refraction, visual acuity, axial length, pupil diameter, and history of spectacle use were examined and compared. According to their spectacle use after surgery, the patients were divided into three groups: the no-spectacle-needed group (34 patients, $26 \%$ ), the distance-spectacle group (29 patients, $22 \%$ ), and the near-spectacle group (66 patients, $51 \%$ ). The patients who used progressive focus spectacles were excluded.

【Results】 The median postoperative spherical equivalent (SE) values were $-0.56 \mathrm{D}$ in the nospectacle-needed group, $-3.13 \mathrm{D}$ in the distance-spectacle group, and -0.13D in the near-spectacle group. The postoperative binocular uncorrected visual acuity was statistically better in the nearspectacle group at $5 \mathrm{~m}$ distance and in the distance-spectacle group at $32 \mathrm{~cm}$ distance. The distance-spectacle group had significantly longer axial length than the other two groups. The no-spectacle-needed group significantly had more patients who did not wear spectacles preoperatively $(P<0.01)$.

【Conclusion】 In patients with monofocal IOL implantation, those with mild myopia in the SE range of $-0.50 \mathrm{D} \sim-1.00 \mathrm{D}$ after surgery and without spectacle wear before surgery tended to require no spectacle wear postoperatively.

\section{I . 緒言}

近年眼内レンズ (intraocular lens: 以下、 IOL）の種類は患者利便性向上を図る目的で多 様化している。多焦点IOLやトーリックIOLの ようなプレミアムIOLの普及が進む中、患者の 術後明視域に対する充実した視機能に対する期 待度は上昇している。しかし、多焦点IOLでは コントラスト感度の低下、グレアやハローなど の問題点も多くあり ${ }^{1)}$ 、費用面に関しても多焦 点IOL と単焦点IOLの費用差に見合う利便性が 得られるか疑問が残る ${ }^{2)}$ 。最近では低加入度数 分節IOL（レンティスコンフォート ${ }^{\circledR}$ ) が保険 適応となったことで、さらにIOLの選択肢が広 がり、どのIOLを選択すれば高い満足度が得ら れるかに注目が集まっている。我々は、以前の 研究で遠見に焦点を合わせた単焦点IOL挿入眼 でも $4.0 \mathrm{~m}$ から $0.8 \mathrm{~m}$ まで裸眼視力が比較的良好

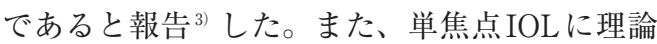
上の調節力が存在しないにも関わらず、遠くも 近くも良く見えるという症例が見られる実地の
体験から、単焦点IOL挿入眼で遠見、近見とも に術後眼鏡不要であった症例は、どのような患 者背景や特性があるのかを後向きに比較検討し た。

\section{II . 対象および方法}

本研究は関西医科大学附属病院 (以下、当 院）臨床研究倫理委員会（2018243）の承認を 得て行われた。対象は 2017 年 3 月から 2018 年 7 月までに当院にて両眼の白内障手術を行った症 例のうち、白内障以外の眼疾患を有しない 129 名（男性 43 名、女性 86 名、平均年齢 $73.97 \pm$ 8.19 歳）に対し白内障手術後の眼鏡使用状況に ついて調查した。

眼鏡使用状況から不要群、遠用眼鏡群、近用 眼鏡群の 3 群に分類し、眼軸長、瞳孔径、術前 の眼鏡使用歴、術前と術後の等価球面値、術後 乱視度数、術後乱視軸、術後两眼開放裸眼視力 について比較検討を行った。また、binocular monovisionによる見えやすさを検証するために 
左右の屈折差について各群で検討した。

視力検査に関しては、検査室の照度750lux、 視標面照度600lux とし、ログマー近点視力表 ${ }^{\circledR}$ (侏半田屋商店製) を用いて測定した、 $5 \mathrm{~m}$ と $32 \mathrm{~cm}$ のデータを診療録から後向きに抽出した。 また瞳孔径はOculus社製Pentacam ${ }^{\otimes}$ 、眼軸長 は(株)カールッァイスメディック社製IOLマス ター『を使用して測定した。

片眼ずつ測定した項目に関しては、データの 検討は 1 人 1 眼で行う原則から、等価球面值が 無限遠方 (0.00D) に近い方の眼を遠用眼、等 価球面值が近見 $32 \mathrm{~cm}(-3.125 \mathrm{D})$ に近い方の眼 を近用眼とし、それぞれで比較検討した。眼軸 長に関しては、測定不能であった症例（不要群 1 名、遠用眼鏡群 2 名、近用眼鏡群 1 名）は除外 した。また、遠用、近用と目的別眼鏡との関係 を調べる上で、術後に遠近両用眼鏡を装用して いる症例は除外した。

統計解析について、眼鏡使用歴はカイ二乗 検定を選択し、それ以外の項目に関しては Kruskal-Wallis の順位検定を行い posthoctest と して多重比較検定であるSteel-Dwass 法を選択 した。また、術後の眼鏡不要性に関する要因分 析として重回帰分析を行った。

\section{III. 結果}

3 群の内訳は、不要群 34 例 $(26 \%)$ 、遠用眼 鏡群 29 例 (22\%)、近用眼鏡群 66例 (51\%) で あった。それぞれの年齢、男女比については表 1 にて示す。

眼軸長の中央値（第一四分位点～第三四分位 点）は、表 1 に示す通りで、不要群と近用眼鏡 群の眼軸長に有意差はなく、遠用眼鏡群が他群 と比較して有意に長眼軸であった $(\mathrm{p}<0.01$, 図 1)。

瞳孔径は各群間に有意差はなかった（表1）。 術前の眼鏡使用歴は、回答の得られた症例 で、不要群は34名中 23 名 $(68 \%$ ）が使用（遠 用眼鏡 7 名、近用眼鏡 10 名、遠近両用眼鏡 6 名)、遠用眼鏡群は 27 名中全員 $(100 \%)$ が使 用 (遠用眼鏡 15 名、近用眼鏡 4 名、遠近両用眼 鏡 8 名)、近用眼鏡群は 65 人中 61 人 $(94 \%)$ が 使用 (遠用眼鏡 7 名、近用眼鏡 36 名、遠近两用 眼鏡 18名）と、不要群で術前眼鏡不使用者が多 くみられた $(\mathrm{p}<0.01)$ 。

術前術後の等価球面値は表 1 に示す通りで、 遠用眼鏡群が最も近視寄りとなり $(\mathrm{p}<0.01) 、$ 術前の近用眼は有意差が出なかったものの、不 要群の方が近用眼鏡群よりも近視寄りとなった

表 13 群間の比較

\begin{tabular}{|c|c|c|c|}
\hline & 不要群 & 遠用眼鏡群 & 近用眼鏡群 \\
\hline 人数(名) & 34 & 29 & 66 \\
\hline 年齢(歳) & $74.35 \pm 9.09$ & $70.59 \pm 8.65$ & $75.26 \pm 7.13$ \\
\hline 男女(名) & 男性8女性26 & 男性9 女性20 & 男性26女性40 \\
\hline 眼軸長【遠用眼】(mm) & $23.22(22.58 \sim 23.78)$ & $25.31(24.57 \sim 26.46)$ & $23.35(22.75 \sim 23.81)$ \\
\hline 眼軸長【近用眼】(mm) & $23.23(22.58 \sim 23.71)$ & $25.33(24.23 \sim 26.68)$ & $23.39(22.75 \sim 23.72)$ \\
\hline 瞳孔径【遠用眼】(mm) & $2.37(2.21 \sim 2.66)$ & $2.45(2.25 \sim 2.62)$ & $2.35(2.07 \sim 2.56)$ \\
\hline 瞳孔径【近用眼】(mm) & $2.33(2.12 \sim 2.56)$ & $2.36(2.23 \sim 2.57)$ & $2.38(2.12 \sim 2.58)$ \\
\hline 術前眼鏡使用歴(\%) & 68 & 100 & 94 \\
\hline 術前等価球面値【遠用眼】(D) & $+0.06(-2.09 \sim+1.00)$ & $-5.38(-7.63 \sim-2.75)$ & $+0.81(-0.22 \sim+1.84)$ \\
\hline 術前等価球面値【近用眼】(D) & $+0.13(-2.13 \sim+1.53)$ & $-5.25(-9.88 \sim-3.00)$ & $+0.63(0 \sim+1.75)$ \\
\hline 術後等価球面値【遠用眼】(D) & $-0.56(-0.97 \sim-0.03)$ & $-3.13(-3.63 \sim-2.25)$ & $-0.13(-0.47 \sim+0.13)$ \\
\hline 術後等価球面值【近用眼】(D) & $-0.88(-1.25 \sim-0.50)$ & $-3.13(-3.50 \sim-2.75)$ & $-0.38(-0.75 \sim-0.13)$ \\
\hline 術後乱視度数【遠用眼】(D) & $-1.00(-1.44 \sim-0.25)$ & $-1.00(-1.25 \sim-0.75)$ & $-0.75(-1.00 \sim-0.31)$ \\
\hline 術後乱視度数【近用眼】(D) & $-1.00(-1.25 \sim-0.50)$ & $-0.75(-1.25 \sim-0.50)$ & $-0.75(-1.50 \sim-0.50)$ \\
\hline \multirow[t]{3}{*}{ 術後乱視軸【遠用眼】％) } & 直乱視 27 & 直乱視 28 & 直乱視 15 \\
\hline & 斜乱視 32 & 斜乱視 38 & 斜乱視 33 \\
\hline & 倒乱視 41 & 倒乱視 34 & 倒乱視 52 \\
\hline \multirow[t]{3}{*}{ 術後乱視【近用眼】(\%) } & 直乱視 21 & 直乱視 35 & 直乱視 12 \\
\hline & 斜乱視 44 & 斜乱視 48 & 斜乱視 30 \\
\hline & 倒乱視 35 & 倒乱視 17 & 倒乱視 58 \\
\hline 術後両眼開放視力【5m】(logMAR) & $0.3(0.1 \sim 0.4)$ & $0.6(0.4 \sim 0.9)$ & $0.2(0 \sim 0.2)$ \\
\hline 術後両眼開放視力【 $32 \mathrm{~cm} 】(\log M A R)$ & $0.5(0.4 \sim 0.6)$ & $0.2(0.1 \sim 0.4)$ & $0.6(0.4 \sim 0.6)$ \\
\hline 屈折左右差(D) & $0.38(0.16 \sim 0.72)$ & $0.38(0.25 \sim 0.63)$ & $0.31(0.13 \sim 0.50)$ \\
\hline
\end{tabular}



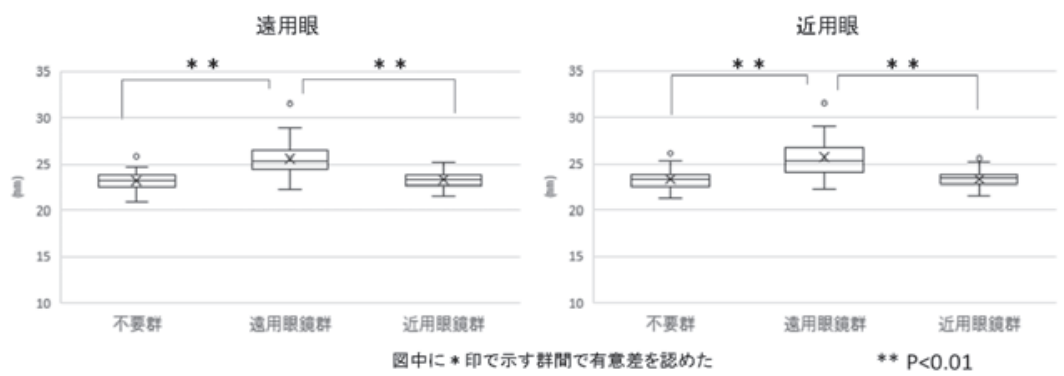

図 1 眼軸長

3 群間の眼軸長を遠用眼（左図）、近用眼（右図）で示す。

眼軸長は遠用眼、近用眼ともに、遠用眼鏡群が他群に比べ有意に長眼軸であっ た。 $(\mathrm{p}<0.01)$
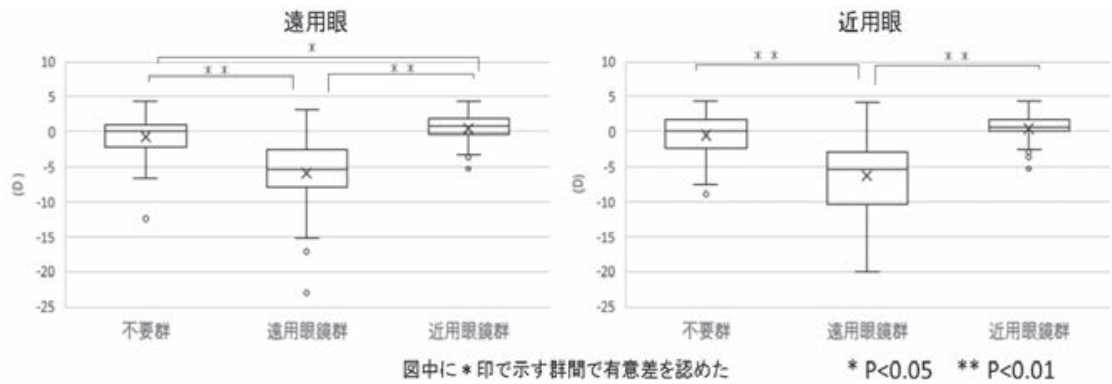

a

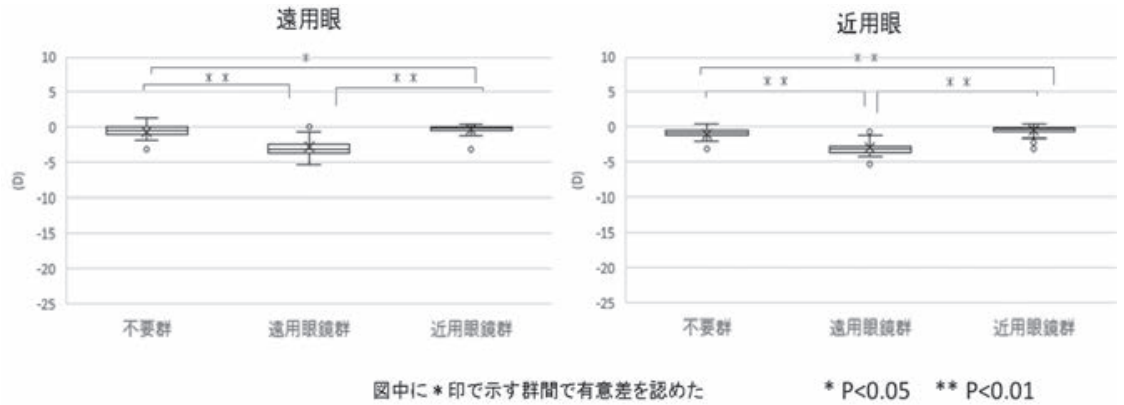

b

四 2 等価球面値

a. 術前等価球面值

3 群間の術前等価球面值を遠用眼（左図）、近用眼（右図）で示す。 術前の等価球面值は遠用眼で遠用眼鏡群、不要群、近用眼鏡群の順で近視寄りで あった。近用眼では遠用眼鏡群が有意に近視寄りであった。

b. 術後等価球面值

3 群間の術後等価球面值を遠用眼（左図）、近用眼（右図）で示す。

術後の等価球面值は遠用眼、近用眼ともに遠用眼鏡群、不要群、近用眼鏡群の順 で近視寄りであった。 

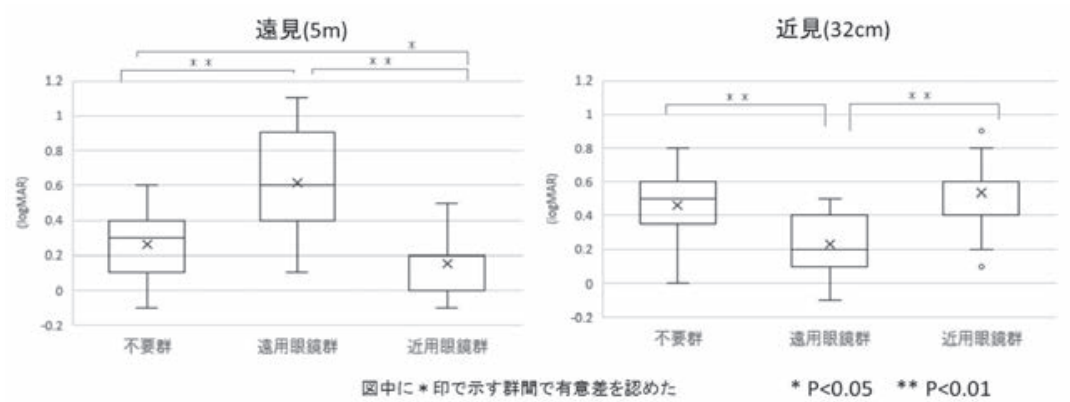

図3 術後両眼開放裸眼視力

3 群間の術後両眼開放裸眼視力を遠見 (左図)、近見（右図）で示す。

遠見 $(5 \mathrm{~m})$ の術後両眼開放裸眼視力は、近用眼鏡群、不要群、遠用眼鏡群の順 で良好で、近見 $(32 \mathrm{~cm})$ の術後両眼開放裸眼視力は遠用眼鏡群が最も良好であ った。

表 2 眼鏡不要の影響因子に関する重回帰分析結果

\begin{tabular}{|c|c|c|c|c|c|}
\hline & 回帰係数 & 漂準回帰係数 & $\mathrm{t}$ 值 & P值 & 判定 \\
\hline 眼軸長(遠用眼) & 0.14 & 0.25 & 2.14 & 0.03 & * \\
\hline 眼軸長(近用眼) & 0.11 & 0.20 & 1.76 & 0.08 & \\
\hline 瞳孔径(遠用眼) & -0.16 & -0.08 & -0.87 & 0.39 & \\
\hline 睡孔径(近用眼) & 0.05 & 0.02 & 0.28 & 0.78 & \\
\hline 眼頡使用歴 & 0.84 & 0.32 & 3.96 & $<0.01$ & $* *$ \\
\hline 術前等価球面値(遠用眼) & 0.04 & 0.19 & 1.67 & 0.10 & \\
\hline 術前等価球面値(近用眼) & 0.02 & 0.12 & 1.03 & 0.30 & \\
\hline 術後等価球面値(遠用眼) & -0.20 & -0.31 & -0.96 & 0.34 & \\
\hline 断後等価球面値(近用眼) & 0.38 & 0.56 & 1.68 & 0.10 & \\
\hline 術後乱視度数(遠用眼) & 0.07 & 0.06 & 0.73 & 0.47 & \\
\hline 術後乱視度数(近用眼) & -0.05 & -0.04 & -0.48 & 0.63 & \\
\hline 術後乱視軸(遠用眼) & 0.11 & 0.10 & 1.15 & 0.25 & \\
\hline 術後乱視軸(近用眼) & 0.11 & 0.10 & 1.14 & 0.26 & \\
\hline 術後両眼裸眼視力 $(5 \mathrm{~m})$ & -0.37 & -0.12 & -1.12 & 0.27 & \\
\hline 術後両眼裸眼視力 $(32 \mathrm{~cm})$ & 0.37 & 0.09 & 0.88 & 0.38 & \\
\hline 座折左右差 & -0.01 & 0.00 & -0.05 & 0.96 & \\
\hline
\end{tabular}

(術前後遠用眼 $\mathrm{p}<0.05$, 術後近用眼 $\mathrm{p}<0.01$ 、図 2 , a b)。

術後乱視度数は各群間で有意差はなかった。 また、術後乱視軸に関しては近用眼で遠用眼鏡 群と近用眼鏡群に有意差がみられ、遠用眼鏡 群に直乱視、近用眼鏡群に倒乱視が多くみられ た。不要群はどの群と比較しても有意差はな かった $(\mathrm{p}<0.05$, 表 1$)$ 。

術後両眼開放裸眼視力（logMAR）は表 1 に 示す通りで、術後両眼開放遠見裸眼視力 $(5 \mathrm{~m})$ は近用眼鏡群が遠用眼鏡群 $(\mathrm{p}<0.01)$ 、不要群 $（ \mathrm{p}<0.05 ） に$ に比べ有意に良好で、遠用眼鏡群が 最も不良であった。また術後両眼開放近見裸眼 視力 $(32 \mathrm{~cm})$ は遠用眼鏡群が最も良好であっ たが $(\mathrm{p}<0.01)$ 、不要群と近用眼鏡群には有意 差がなかった（図3）。
術後屈折左右差は各群間で有意差はなかった (表1)。

術後眼鏡不要性に最も影響与える要因を検索 するために、重回帰分析を行った結果を表 2 に 示す。今回我々が調查した16因子を用いた回 帰係数については、遠用眼の眼軸長（ $\mathrm{p}=0.03 ） 、$ 眼鏡使用歴（ $\mathrm{p}<0.01 ）$ の 2 項目で有意差がみら れ、重回帰分析の結果からも術後の眼鏡不要性 に関わる要因として最も有用であるのは術前の 眼鏡使用歴であるという結果が得られた。

不要群で術前に眼鏡を使用していた 23 名につ いて術前と術後の屈折変化を比較したところ、 術前の等価球面値は遠用眼 $0.88(-1.19 \sim 1.75)$ D、近用眼 $0.50(-1.31 \sim 1.00)$ D、術後の等価 球面值は遠用眼 $-0.63(-0.94 \sim-0.06)$ D、近用 眼 $-0.75(-1.13 \sim-0.44)$ D であり、遠用眼、近 
用眼どちらにおいても有意に術後の等価球面値 が近視寄りであった（遠用眼 $\mathrm{p}=0.03$ 、近用眼 $\mathrm{p}=0.03)$ 。また、これらの症例の術後屈折左右 差は $0.25 （ 0.13 \sim 0.75 ）$ D であり遠用眼鏡群、近 用眼鏡群と有意差はなかった。

\section{IV. 考按}

眼鏡使用状況として不要群、遠用眼鏡群、近 用眼鏡群を比較すると、遠用眼鏡群は長眼軸で 術前に近視の割合が高く、術後も-3.00D 程度 の近視を残した症例であった。不要群と近用眼 鏡群では眼軸長に有意差はなかったが、術後 の等価球面値の中央值は、不要群では遠用眼で $-0.56 \mathrm{D}$ 、近用眼で-0.88Dであり、近用眼鏡群で は遠用眼で-0.13D、近用眼で-0.38D で有意差が みられた。裸眼近見視力が良好となるには、術 後-1.00D 前後の軽い近視となる事が望ましいと いう報告 ${ }^{4)}$ や、術後の等価球面値を $-0.80 \mathrm{D}$ 程度 にすれば、眼鏡装用なしで生活できる可能性が 増すといった報告 ${ }^{5}$ があり、今回の結果からも 両眼ともに-0.50D〜-1.00Dの屈折の範囲に収 まれば術後眼鏡が不要になる可能性が高いと考 える。

今回検討した 3 群について、不要群は他群と 比較して偽調節が多く働いているのではないか と考えた。偽調節とは無水晶体眼やIOL扱入 眼でも起こる調節類似の現象 ${ }^{6}$ であり、偽調節 と乱視度数との関係については、2.00D 前後の 乱視が裸眼視力に有利に働くこと や、乱視と 偽調節量に負の相関があったという報告 ${ }^{7}$ があ る一方で、偽調節と乱視量に相関はないといっ た報告 ${ }^{8)}$ もる。また、瞳孔径に関しては、睹 孔径が小さいと焦点深度が深くなり明視範囲が 大きくなると報告 ${ }^{6}$ さされているが、偽水晶体眼 にみられる偽調節は縮曈のみの関与は少ないと いった報告9) も見られる。今回検討した 3 群間 では術後乱視度数、瞳孔径ともに 3 群間に有意 差はなく、不要群においては瞳孔や乱視が果た す役割は小さいと考える。偽調節と乱視軸に関 しては、倒乱視の方が直乱視より優れていると いう報告 ${ }^{10)}$ もあるが、直乱視と倒乱視で有意 差はなかったという報告 ${ }^{11}$ も見られた。その
他に、白内障術後の人は乱視が同程度であった 場合、直乱視の方が倒乱視より裸眼視力が良好 であるという報告がある ${ }^{12)}$ 。本研究では近用眼 において遠用眼鏡群と近用眼鏡群の乱視軸に関 して有意差がみられ、遠用眼鏡群では直乱視が 多く、近用眼鏡群では倒乱視が多い傾向にあっ た。このことから近見視には直乱視が有用に働 く可能性が示唆された。しかし、不要群はどの 群に対しても有意差がなかったことから、眼鏡 不要性に乱視軸の明らかな関与は認められな かった。とりわけ、不要群は術前に眼鏡を使用 していなかった症例が他群に比べ多いことは、 不要群は術前に未矯正でぼやけた視界に慣れて いるため、術後も眼鏡不要で日常生活に支障が ないのではないかと考えた。植村らは、眼内レ ンズでの偽調節には視覚中枢におけるボケの検

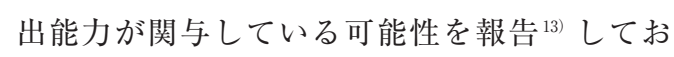
り、我々の仮説を後押しするものである。つま り、術前に眼鏡不使用であった場合、像のボケ に対する寛容性が高く、術後に眼鏡不要となる 割合が高くなると考えられる。重回帰分析の結 果からも、術前の眼鏡使用歴が術後眼鏡不要性 の重要な因子と判明したことで、手術前の問診 で眼鏡使用歴を問うことが術後の眼鏡不使用の 可能性を予測し、また必要となる眼鏡をアドバ イスできる可能性がある。その一方で、不要群 のうち術前に眼鏡を使用していた 23 名に関して は、術前に軽度の遠視があり、術後の等価球面 值の中央値が遠用眼で $-0.63 \mathrm{D}$ 、近用眼で $-0.75 \mathrm{D}$ と軽度近視眼であったことから、前述した屈折 が見え方に影響を与えた可能性が高く、術後の 見え方がより生活習慣に馴染んだ結果、眼鏡装 用なしで生活できるようになったためであると 考えられる。

屈折左右差については、全群間において有意 差はなかったが、不要群と近用眼鏡群を比較し た場合に $1.25 \mathrm{D} \sim 1.50 \mathrm{D}$ の屈折左右差がある症 例は近用眼鏡群では見られず、不要群では 5 例 みられた。しかし全群間で屈折左右差が2.00D を超える症例は見られなかった。また、不要群 で術前に眼鏡を使用していた 23 名と、遠用眼 鏡群、近用眼鏡群の 3 群で屈折左右差を比較す ると 3 群間に有意差はなく、屈折左右差の関与 
は見られなかった。モノビジョン法 ${ }^{14)}$ では、非 優位眼の屈折值が-2.00D 未満では十分な近方視 力が得られず、 $-2.50 \mathrm{D}$ 以上では不等像視による 違和感や両眼視機能の低下を生じる症例の割合 が多くなることから、非優位眼の屈折值として $-2.00 \mathrm{D}$ から $-2.50 \mathrm{D}$ 用いることが推奨されて きた。しかし、最近の報告によると偽調節効果 を利用して非優位眼の屈折值を-1.50D とする報 告や ${ }^{15)}$ 、屈折左右差を $0.50 \mathrm{D}$ とする報告 ${ }^{16)}$ も 久 られ、屈折差を少なくしたマイルドモノビジョ ン法が有用であるとの報告から、当院において も意図的に屈折差を少なくしたモノビジョン法 が行われている可能性はあるが、今回の検討で は左右の屈折值に有意差は見られず、これは本 研究の限界を示した。

本研究の結果から術後の等価球面值が両眼と もに-0.50D〜-1.00D以内の軽度近視に収まれ ば、術後眼鏡不要になる可能性が高くなると言 える。また、術後眼鏡が必要か、どの種類の眼 鏡が必要か、については術前の眼鏡使用歴が大 きく関与することがわかった。

利益相反 : 利益相反公表基準に該当なし

\section{参考文献}

1) Woodward MA, Randleman JB, Stulting RD: Dissatisfaction after multifocal intraocular lens implanation. J Cataract Refract Surg35: 992-997, 2009.

2 ) ビッセン宮島弘子, 南慶一郎, 神前太郎, 吉田 伸利: 多焦点眼内レンズの挿入を検討してい る患者に対する多施設アンケート調查. あた らしい眼科 35(9): 1281-1285, 2018.

3 ）佐々木由佳, 仲村永江, 長澤佳恵, 宮田律子, 城戸麻耶, 井上 睦, 他: 単焦点眼内レンズ挿 入眼の裸眼での視力特性. 日視会誌 46: 129136, 2017.

4 ）芳賀照行: 単焦点眼内レンズ挿入眼において
眼鏡が必要でない例. 臨眼 92:1706-1708, 1998.

5 ) 野村秀樹, 下方浩史: 白内障術後屈折度と Quality of Vison. 眼紀 49: 935-939, 1998.

6 ) 魚里 博: 調節および偽調節。眼科手術 5: 223-233, 1992.

7 ) 名和良晃, 中塚三恵子, 吉井稔章, 小南雅也, 原 嘉昭, 魚里 博: 近見1.0の視標を用いた 偽調節の測定. 日眼会誌 105(3): 171-176, 2001.

8 ) 岡野正樹, 田所康徳, 長谷部聡, 大月 洋: 眼 内レンズ挿入眼における偽調節 - 他覚的測定 の試み - . 眼紀 42: 415-420, 1991.

9 ）内山幸昌, 清水由規, 熊谷正也, 岩澤博俊: 偽 水晶体眼の偽調節と瞳孔径. 臨眼 49(6): 11931196, 1995.

10) Trindade F,Oliveira A,Frasson M:Benefit of against-the-rule astigmatism to uncorrected near acuity.J Cataract Refract Surg,23:8285,1997.

11）西 智, 名和良晃, 増田紀子, 吉井稔章, 植村 佐和子, 加藤佳子, 他: 偽調節と倒乱視, 直乱 視の関係. IOL \& RS, 17: 445-448, 2003.

12) 大谷伸一郎, 宮田和典, 阪上祐志, 鮫島知一, 高橋哲也, 中原正彰: 白内障手術時における 乱視矯正同時手術の適応. IOL\&RS, 15: 142145, 2001.

13）植村佐知子, 魚里 博, 西信元嗣: 偽水晶体眼 における偽調節について. 眼紀 41: 209-314, 1990.

14）清水公也: モノビジョン白内障手術による老 視治療。あたらしい眼科22(8): 1067-1072, 2005.

15）江黒友春, 天野理恵, 常廣俊太郎, 飯田嘉彦, 伊藤美沙絵, 清水公也: 眼内レンズによるマ イルドモノビジョン法の満足度に影響する因 子の検討. 臨眼66(8): 1161-1164, 2012.

16) Beiko GH: Comparison of visual results with accommodating intraocular lenses versus mini-monovision with a monofocal intraocular lens. J Cataract Refract Surg, 39:48-55, 2013. 